\title{
Mouse Plasma Cell Myeloma
}

National Cancer Institute

\section{Source}

National Cancer Institute. Mouse Plasma Cell Myeloma. NCI Thesaurus. Code C125417.

Plasma cell myeloma occurring in a mouse. 